\title{
Developing an Integrated Land Allocation model based on Linear Programming and Game Theory
}

\section{farzam hasti ( $\square$ farzam.hasti@gmail.com )}

Gorgan University of Agricultural Sciences and Natural Resources

Abdolrasoul SalmanMahiny

Gorgan University of Agricultural Sciences and Natural Resources

Haydar Rouhi

Gorgan University of Agricultural Sciences and Natural Resources

Yousef Sakieh

LUT University - Lahti Campus

\section{Ramtin Joolaei}

Gorgan University of Agricultural Sciences and Natural Resources

\section{Negin Pezhooli}

Iran University of Science and Technology

\section{Research Article}

Keywords: Game theory, Land allocation, Linear programming, Geospatial information system (GIS)

Posted Date: January 20th, 2022

DOI: https://doi.org/10.21203/rs.3.rs-553638/v1

License: (c) (i) This work is licensed under a Creative Commons Attribution 4.0 International License. Read Full License 


\section{Abstract}

Land use configuration in any given landscape is the result of a multi-objective optimization process, which takes into account different ecological, economic and social factors. In this process, coordinating stakeholders is a key factor to successful spatial land use optimization. Stakeholders need to be modeled as players who have the ability to interact with each other towards their best solution, while considering multiple goals and constraints at the same time. Game theory provides a tool for land use planners to model and analyze such interactions. In order to apply the spatial allocation model and address stakeholder conflicts, an integrated model based on linear programming and game theory was designed in the present study. For implementing such model, we conducted an optimal land use allocation process through multi-objective land allocation (MOLA) and linear programming methods. Then, two groups of environmental and land development players were considered to implement the optimization model. The game algorithm was used to select the appropriate constraint so that the result was acceptable to all stakeholders. The results showed that in the third round of the game, the decision-making process and the optimization of land uses reached the desired Nash Equilibrium state and the conflict between stakeholders was resolved. Ultimately, in order to localize the results, a suitable solution was presented in GIS environment.

\section{Introduction}

Land use planning is a complex process in which all land use types are evaluated simultaneously to set a systematic framework that takes into account the conflicting goals and constraints of landowners (Kaiser et al. 1995; Guoxin et al. 2004; Ligmann-Zielinska et al. 2008; Cao et al. 2011; Batty, 2018; Song and Chen 2018; Maleki et al. 2020). Spatial optimization of land use is a complex decision-making problem with multiple antagonistic objectives from different influential parties and proper coordination between land use conflicts is a major key to a successful spatial optimization. The limited quantities of land resources and their suitability for different utilities are the main reasons for such conflicts (Chen, 2007; Maleki et al. 2020). From a spatial point of view, land use conflicts can be considered as competition of different land use types over a shared landscape to occupy land. However, in principle, such competitions are mainly conflicts of interest between several stakeholders (Zhang Li and Fung 2012). Regarding land use management and optimization, selecting a suitable alternative from the set of available options is a challenging task (Lund and Palmer 1997; Gu et al. 2021) since criteria are contradictory and hardly reconcilable, and any decision can cause objection from one or multiple parties, who think their interests are neglected (Lee and Chang 2005) and it is often difficult to satisfy all stakeholders with different interests, values and perspectives (Shields et al. 1999; Collins and Kumral 2020). Considering land use challenges, the contradiction between the economic benefits of land use development (e.g. timber cultivation, agricultural practices and recreational activities) and ecological values (e.g. water and soil conservation and eutrophication reduction) has been well-documented in the literature (Lund and Palmer 1997; Jana et al. 2019). The contradiction between the environmental approach of governmental decision-makers in the Zagros basins, Iran, and the economic interests of local people living in these basins has led to the situation that majority of decision-makers are trying to establish a balance between such conflicting goals. In this context, silo approaches and excluding influential layers and parties in the region from decision making have only led to trade-off among different goals and negative feedbacks and feedback loops among players (Raquel et al. 2007).

Many researchers have conducted extensive researches on land use optimization and allocation. Existing optimization models can be roughly divided into the following three categories: linear programming models, cellular automation (CA) models and intelligent algorithm models (Liu at al. 2015). Linear programming models can quickly detect the structure of the optimal land use in response to specific goals and constraints (Arthur and Nalle 1997; Chuvieco 1993; Sadeghi et al. 2009). Automated cellular models are based on land use conversion principles and follow a bottom-up approach to create different land use patterns under different conditions ( $\mathrm{Li}$ and Yeh 2000, 2002). There are various machine learning and artificial intelligence algorithms in the literature amongst which simulated annealing (Aerts et al. 2003), particle 
swarm optimization (Liu et al. 2012; Liu et al. 2012; Liu et al. 2012; Ye et al. 2021), ant colony (Li, Shi, He, and Liu 2011; Liu, Li, et al. 2012; Tang et al. 2020) and genetic algorithm (Liu et al. 2015; Ozsari et al. 2021) are important representatives to mention. Geographic information systems (GIS) play an important role in the application of intelligent algorithms in spatial optimization of land use (Wu and Grubesic 2010). GIS is used to process and visualize spatial data for these algorithms; however, these models do not take into account local land use conflicts and lack a coordinated game-based mechanism for solving local land use competitions (Liu et al. 2015).

Game theory, which was first introduced with the pioneering work of von Neumann and Morgenstern (1944), is the study of mathematical models of conflict and cooperation between decision makers (Bočková et al. 2015). It is also a powerful tool in determining the equilibrium among decision makers and it is used to analyze situations where stakeholders' decisions affect those of others. Game theory has been used in various fields such as economics (Camerer, 1997) and social sciences (Myerson, 1992), water resources management (Parrachino et al. 2006a, b; Carraro et al. 2007; Homayounfar et al. 2010; Sobuhi, 2010; Liu at al. 2021; Mohammadifar et al. 2021), optimal groundwater consumption (Mazandarani zadeh et al. 2010; Pourzand and Zibaei 2010; Nazari et al. 2020; Yazdian et al. 2021), wood market (Mohammadi Limayi, 2006, 2007), paper market (Mohammadi Limayi, 2010), forest management (Rodriguez et al. 2009; Shahi and Kant 2007; Ikonen et al. 2020) and watershed management (Lee, 2012; Moradi and Mohammadi Limaei 2018; Adhami et al. 2020). The game theory can simulate the decision-making behavior of different stakeholders with conflicting interests and facilitate reaching a consensus among them (Rasmusen, 2001; Zhang, 2004; Maleki et al. 2020). The application of game theory in the context of land use change can be categorized into monitoring $(\mathrm{Wu}, \mathrm{Wu}$, and $\mathrm{Shen}$ 2005) multi-objective optimization (Lee, 2012), and resolving land use conflicts (Hui and Bao 2013; Maleki. et al. 2020) studies. However, game theory methods are rarely associated with land use allocation models and in this research, we have attempted to make a connection between land use optimization and conflict resolution to develop an informed spatial allocation model. In this study, we first optimize different land use categories using the multi-objective land allocation (MOLA) method and linear programming. Then, a contradiction is simulated during the land allocation process, which will ultimately be resolved using the game theory algorithm. Despite much research on separate application of game theory and linear programming in environmental studies, their integrated application for developing land allocation

models is a less noted attempt in the literature. Therefore, the main objective of this study is to develop an integrated land allocation model to explore the potential of different land use optimization methods such as MOLA, game theory and linear planning when combined together. In addition, this study provides a participatory basis to include the views of different stakeholders during the decision-making process which supports application of the results and provides a spatial decision support system, which helps decision makers to simulate and quantify the probable effects of strategies adopted by influential parties in the region.

\section{Material And Methods}

The study site covers Gorgan and Kordkoy cities spanning over an area of 243921 hectares, located in Golestan Province, northeastern Iran. Gorgan is located at $48^{\circ} 28^{\prime}$ ' 54" northern longitudes and 48 49' $36^{\prime \prime}$ eastern latitudes and Kordkuy is located at $47.88^{\circ} 6^{\prime} 54^{\prime \prime}$ northern longitudes and $30.12^{\circ} 47^{\prime} 36^{\prime \prime}$ eastern latitudes. The population size in Gorgan and Korkoy is 462455 and 70244, respectively (Census Yearbook of Golestan Province 2013). Fig. 1 shows the geographical location of the study area.

The trend of land use change in the study area shows that in 1984, forest cover accounted for more than $50 \%$ of the area, while over time, their area has gradually declined, and by 2036 , the area of forest cover is anticipated to be to less than $20 \%$ of its current total area (Asadollahi and SalmanMahiny 2017). Forest lands in this region have mainly been transformed into land use categories such as agriculture and urban areas. Such land use conversions have been occurring mostly based on economic interests with no respect to land potential and ecologically valuable ecosystems in the region. Therefore, in order to protect forest and protected lands, and simultaneously, regulate land development plans 
in accordance with land capability of the area, governmental authorities need to find a balance between economic players and environmental stakeholders whose interests are conflicting in the region. The environmental stakeholders include proenvironmental organizations and bodies, as well as pro-environmental people. The economic players include government, land developers and private companies. Thus, in order to resolve conflicts between pro-environmental stakeholders and land developers, a solution based on game theory and linear planning can be achieved, so that the results of land management would be acceptable to all, which can later control unplanned and uncontrolled land use changes in this area.

This study is conducted through three main steps to allocate land uses. In the first step, an initial multi-objective land allocation model is presented using the MOLA method. The purpose of this step is to provide a model of primary land use allocation based on the potential and natural characteristics of the region. In the second step, the initial land use allocation model is updated according to higher goals such as the interests of pro-environmental stakeholders and land developers (i.e. secondary land use allocation). Finally, in the third step, in order to implement the secondary land use allocation, it is necessary to resolve the existing conflicts between the stakeholders with their conflicting interests, so that the results of land use allocation are acceptable to all of them. To achieve this goal, we will use a designed game algorithm. The general framework of the work is given in Fig. 2. First, we examined land suitability using the Multi Criteria Evaluation (MCE) method for seven selected land uses. In the next step, we used the MOLA method for land allocation and land use planning. Then, we used the multi-objective linear programming method to better optimize land uses and improve the MOLA outputs. At this stage, to meet the needs of different stakeholders in the study area, two objectives of minimizing runoff depth and maximizing profits from each land use were selected for land use optimization. Also, restrictions were designed to implement the objectives according to the needs of each stakeholder group. Despite various limitations, it was not possible to continue optimization process, and therefore. the game theory approach was implemented to resolve the conflict. Finally, by resolving the conflict, based on the result of the game theory, one of the constraints was selected as the constraint accepted by all stakeholders, and the multi-objective linear programming was performed based on these constraints to optimize and upgrade MOLA outputs.

\subsection{Land use optimization}

The MOLA method was used to optimize different land use categories in the study area. In doing so, based on ecological characteristics of the region, research objectives, experts' opinions and past studies, land use categories in the area were defined as follows: warm and cold water aquaculture, agriculture, forestry, urban and rural developments, conservation and rangelands. Then, the relevant data and map layers were collected and standardized. In the next step, using MCE for each land use type, a suitability map was prepared, which fed into MOLA.

\subsubsection{Database preparation and multi-criteria evaluation}

During the MOLA process, first a land suitability analysis for different land use categories is conducted. In this regard, based on objectives of the study, local knowledge of the research location, data availability and former studies in the region, hydrothermal aquaculture, cold-water aquaculture, agriculture, forestry, urban and rural development, conservation and rangeland were selected as land use categories. The required factors for each land use were determined and a suitability map for each land use was prepared using the MCE method. In this case, important factors including elevation, slope, geographical aspect, geological characteristics, soil and erosion risk were obtained mainly from digital elevation model (DEM) of the study area. The DEM of the area was acquired from National Cartographic Center (NCC) of Iran. In addition, hydrographic map, plant type and vegetation, climate of the region, bedrock, percentage of vegetation density, soil type and texture (including drainage conditions, soil depth and structure as well as fertility), distance from the road, distance from residential areas, hydrological map of the study area were also prepared. The set of factor layers implemented in this study were obtained from Goragn University of Agricultural Sciences and Natural resources, which is the leading institute in conducting land use planning studies in the region. 
The MCE method evaluates land suitability in response to several environmental criteria. During the MCE process, several map layers are standardized (i.e. fuzzified), weighted and combined to evaluate the suitability of the land for a specific utility. In this regard, in the first step, the above-mentioned set of influential criteria on land suitability for targeted land use categories in our study were identified. The set of criteria is divided into constraints and factors. Constraints include those Boolean criteria that shows the suitability of the land in a 0 and 1 fashion. In other words, zero indicates absolute lack of potential and one indicates suitability of the land for the desired land use. In contrast, factors represent the degree of the land suitability in a continuous way, and therefore, the layers with continuous values are standardized using Fuzzy sets theory. It is because each layer has a different measurement scale and it is necessary to standardize the layers to be able to combine them into one single suitability map. The standardization process can be performed by fuzzy membership functions on a scale of 0 to 1 or 0 to 255 (Drobne \& Lisec, 2009). In addition, the relative weight of each factor layer is determined based on Analytical Hierarchy Analysis (AHP) and finally layers are combined into one final suitability map based on Weighted Linear Combination (WLC) method was used (Hasti et al., 2016). The WLC equation is presented as follows:

\section{$\mathrm{MCE}$ for land suitability mapping $=\sum_{i=1}^{n} W i X i \prod C i$}

Eq. 2

where, $W i$ is the AHP-derived relative weight of the factor $i, X i$ is the standardized layer $i, C i$ is constraint $i$ and $\prod$ is he multiplication operator.

MOLA is an iterative allocation process through which a specific area threshold for each land use category is achieved using the corresponding weight of the land use type. In the present study, the aim was to optimize land use categories considering ecological conservation perspectives and economic interests. In case of ecological conservation, the objective was minimizing the probability of runoff depth, and the economic goal was maximizing the profit from each land use. In order to achieve the targeted goals and improve MOLA allocation behavior during spatial optimization process, the multi-objective linear programming method was employed. A multi-objective linear programming model can be defined as follows (Eq. 2):

$$
\begin{aligned}
& \text { Max (or Min) } Z\left({ }_{x}\right)=\left[Z 1\left({ }_{x}\right), Z 2\left({ }_{x}\right), Z 3\left({ }_{x}\right), \ldots, Z p\left({ }_{x}\right)\right] \quad \text { Eq. } 2 \\
& \text { s.t } \quad g_{j} \leq 0, \quad j=1,2, \ldots, n \\
& \quad x_{k} \geq 0, \quad k=1,2, \ldots, n
\end{aligned}
$$

where $\mathrm{Z}(\mathrm{x})$ is an objective function and $\left.\left[\mathrm{Z1}\left({ }_{\mathrm{x}}\right), \mathrm{Z2}(\mathrm{x}), \mathrm{Z} 3_{(\mathrm{x}}\right), \ldots, \mathrm{Zp}\left(\mathrm{x}_{\mathrm{x}}\right)\right]$ is a set of objective functions $\mathrm{G}_{\mathrm{i}}(\mathrm{x})$, $\mathrm{j}$ is the most important constraint and $x_{k}, k$ is the decision variable. The goal of optimization is to find the best acceptable answer, given the limitations and needs of the problem. For a problem, there may be different answers, and to compare them and select the optimal solution, a function called the objective function is defined. The choice of this function depends on the nature of the problem, for example, the objective function can be selected such as profit maximization, employment, runoff minimization, erosion, environmental pollution, etc. Decision variables are variables that are used to write the objective function, such as different types of land use. Constraints are factors that indicate what constraints exist or should be applied to the execution of the objective function.

Land use optimization in watersheds using linear planning and geographic information systems is one of the appropriate management methods to achieve optimal landscape configuration and maximum profit (Riedel, 2003); however, the economic interests must be secured considering ecological and social sustainability aspects (Pfaff and Sanchez, 2004; Ducourtieux et al. 2005). There are also other studies in the literature applying linear programming for land allocation (Shabani, 2010; Chuvieco et al. 2004; Nikkami et al. 2002). 
In order to obtain the runoff depth probability of each land use type, the long-term hydrological impact assessment (LTHIA) model was used in Arc View software environment and the runoff depth probability was extracted. This model provides an estimate of runoff changes, recharge and pollution of non-point sources due to past or predicted land use change to provide a measure of the long-term effects of development on hydrological conditions (Bahadori et al. 2000; Weng, 2001; Ma, 2004). This model was first developed for natural resource managers because they are familiar with land use change in a particular area and have access to land use information and are often interested in studying environmental impacts (Engel et al. 2003). In addition, economic data such as land use profit was retrieved from land use planning database of Golestan Province, which was establish in 2014.

The purpose of this study is to integrate game theory into the land allocation process. At this stage, in order to simulate contradictive perspectives during the land use allocation, two target categories can be considered for the implementation of multi-objective linear programming. In other words, there are two categories of constraints for the implementation of linear planning, which include constraints designed by stakeholders seeking environmental protection and land developers trying to maximize economic interests. Therefore, with two sets of constraints, it is not possible to implement land use allocation by linear programming. In this regard, each of the stakeholders wants to implement their goals, and at this stage, game theory can be used to resolve the simulated conflict.

\subsection{Game algorithm}

At this phase, in order to resolve the simulated conflict, we can implement the general framework and the game algorithm (Fig. 3).

Fig. 2 shows the game algorithm designed for this study. As shown in the figure, after the initial (MOLA) and the second (linear programming) land allocation, we have two sets of constraints according to the different needs of the stakeholders (environmental and economic), and therefore, the optimization process will stop (conflict). According to the various scenarios and strategies that are designed, which we will explain in the following, we will use game theory to resolve this conflict and select one of the limitations to continue the optimization process. This algorithm shows that in each stage of the game, if the result is Nash equilibrium, which is acceptable to all players, the created conflict will be resolved. The result of resolving the conflict is selection of one of the limitations for implementing linear programming and final land allocation.

Once the game algorithm has been designed, it is necessary to devise strategies for each step of the algorithm to simulate decision conditions and selection of players. Specifically, there are different categorizations of games. Games, in terms of format, can be divided into two forms of strategy or normal and wide or tree. Strategy games are a compact form of a game in which players simultaneously coordinate their strategy. Extensive games can also be referred to as a set of normal games (Hasti et al. 2016). Each game contains three main elements including i) players, which is the factor that makes decisions in the game., ii) actions, which is a set of actions defined for each player, and iii) final result, function or preferences, which is the result of each player from his decision according to the rules and scenarios of the game (Hasti et al. 2016). In the present study, the idea of a prisoner puzzle game (non-zero outcome), which is a wellknown example of normal games, was undertaken and the wide form of the game was used to implement it. The conflict is created in such a way that each player accepts his own restrictions and has designed restrictions according to his goals. The designed goal for players in the game is to meet their designed constraints. In other words, the choice of constraints designed by them is more important. In the next stage, game scenarios for each player were determined according to experts' knowledge and the designed goal. The game scenario in the first iteration is presented in Table 1. 
Table 1 Game scenario descriptions in the first iteration

\begin{tabular}{|c|c|c|}
\hline \multicolumn{2}{|l|}{ Player } & \multirow[t]{2}{*}{ Strategy } \\
\hline Economic (EC) player & Environmental (En) player & \\
\hline If selects Ec, constraints = 5 & If selects En, constraints $=5$ & The first strategy \\
\hline If selects Ec, constraints $=10$ & If selects Ec, constraints $=3$ & The second strategy \\
\hline If selects En, constraints = 3 & If selects En, constraints $=10$ & The third strategy \\
\hline If selects En, constraints = 2 & If selects Ec, constraints $=2$ & The fourth strategy \\
\hline
\end{tabular}

To better understand Table 1, for example, the first strategy shows that if the environmental player chooses his constraints (En constraints), he will get 5 points. Also, if the economic player selects his designed constraints (Ec constraints), he gets 5 points. Therefore, Table 1 shows the strategies that each player can choose and the points that he will receive from each choice.

Then, the game model was designed in Gambit 13.1 software and the game results were determined, which included the balance of the game and the usefulness (points) obtained for each player as a result of solving the game. The results show that players have selected their own restrictions and the desired conflict is still present, and consequently, the game enters the second iteration. In the second phase of the game, the objective for each player was to achieve the environmental and land development interests as well as respecting constraints designed by other players. In other words, each of the constraints designed by each group achieves the maximum value of the objective function (minimizing the probability of runoff depth and maximizing the profit from each land use). To do this, the environmental objective function was first implemented based on constraints separately designed in response to environmental conservation and economic benefits. Then, the same procedure was repeated for economic function. In the next step, based on the experts' opinion and according to the results of the multi-objective linear programming for objective functions (based on the constraints designed by each player separately), game scenarios were introduced for each decision of the players. Table 2 shows the game scenario in the second iteration.

Table 2 Game scenario descriptions in the second iteration

\begin{tabular}{|c|c|c|}
\hline \multicolumn{2}{|l|}{ Player } & \multirow[t]{2}{*}{ Strategy } \\
\hline Economic (Ec) player & Environmental (En) player & \\
\hline If selects Ec, constraints= 6 & If selects En, constraints = 6 & The first strategy \\
\hline If selects Ec, constraints $=10$ & If selects Ec, constraints $=4$ & The second strategy \\
\hline If selects En, constraints $=4$ & If selects En, constraints $=10$ & The third strategy \\
\hline If selects En, constraints $=2$ & If selects Ec, constraints $=2$ & The fourth strategy \\
\hline
\end{tabular}

The land use allocation game model was implemented with the second iteration in Gambit 13.1 software. The results of the game including the desirability of the players in each decision and the balance of the game were obtained. Given the nature of the game theory (Nash Equilibrium concept) in predicting player's decisions and game resolution results, it shows that each player selects his or her own constraints as the final decision. Due to outcome of the game, the conflict 
has not yet been resolved and it is not possible to continue the process of optimization and land use allocation. Therefore, due to the nature of the game theory in bargaining and repetition, the game will enter its third phase. In the third phase of the game, more emphasis was placed on the bargaining power of the game theory, and the goal of the players in making decisions was set accordingly. To resolve the conflict, the players' goal was to satisfy the other side based on their required area and needs. To do this, both environmental and land development objective functions were implemented simultaneously with the designed constraints of the ecologists and economists in the WINQSB software. In the next step, based on the results of the implementation of the multi-objective linear programming model (i.e. area allocated to each land use), the goal of each player, the opinion of experts and game decision scenarios were designed (Table 3).

Table 3 Game scenario descriptions in the third phase

\begin{tabular}{|c|c|c|}
\hline \multicolumn{2}{|l|}{ Player } & \multirow[t]{2}{*}{ Strategy } \\
\hline Economic (Ec) player & Environmental (En) player & \\
\hline If selects Ec, constraints= 3 & If selects En, constraints = 8 & The first strategy \\
\hline If selects Ec, constraints= 3 & If selects Ec, constraints $=2$ & The second strategy \\
\hline If selects En, constraints $=5$ & If selects En, constraints $=10$ & The third strategy \\
\hline If selects En, constraints $=4$ & If selects Ec, constraints $=3$ & The fourth strategy \\
\hline
\end{tabular}

The results of the game solution show that the Nash Equilibrium is at the stage where both players choose the designed constraints related to the environment. By negotiation between the players and satisfying each other, the result indicates that the conflict has been resolved and the process of land use allocation continues. In this way, spatial optimization with constraints designed by environmentalists can be implemented in a way that it is acceptable to all stakeholders based on the results of the game algorithm. Due to the nature of game theory, the game can enter other stages until the decisionmaking process finally reaches the Nash Equilibrium. The essence of the game theory is that each player selects a strategy, but the end result depends on the choice of all players. Therefore, each player, to some extent, can control the outcome of the game. The end result varies from person to person, with one player being the best and the other the worst. Thus, the fundamental question is, given the different outcomes for individuals, how does game theory resolve conflict (Samsura et al. 2010) There are different approaches to game theory, however the concept of Nash Equilibrium is often used (Aumann, 1985). Nash Equilibrium can be introduced as a strategy choice for each player such that no player is willing to change and the strategy chosen by each player is the best response to the strategy chosen by other players. The best means that changing this strategy will not increase the result (Samsura et al. 2010). The following equation shows the Nash Equilibrium in a game:

$$
U_{i}\left(a^{*}\right)=U_{i}\left(a_{1} *, a_{2}{ }^{*}, \ldots, a_{n}{ }^{*}\right) \geq U_{i}\left(a_{1} *, a_{2}{ }^{*}, \ldots, a_{n}{ }^{*}\right) \quad \text { Eq. } 2
$$

In this regard, Ui is the utility of the i-th player and the actions of each player in different situations. According to the above explanations, by reaching the Nash Equilibrium, the result of the game is accepted by the majority, and the objective functions were performed with environmental constraints.

For model sensitivity analysis, it is also necessary to examine the expected outputs by changing the model inputs used in this research. As explained, the purpose of this study is to improve land allocation results from the MOLA analysis with objectives such as minimizing runoff depth and maximizing profits using linear programming, and therefore, the result of linear planning changes land allocation areas. For sensitivity analysis of the model, we implemented the L-THIA model 
once with the initial land allocation map (MOLA) as the input land use layer and once with maps from linear programming (one time with environmental stakeholder constraints and one time with economic stakeholder constraints). Finally, we examined the sensitivity of the model and changes in runoff depth in response to changes in land allocation (Table 8).

\section{Results}

First, for each of the seven land uses selected in the study area, we obtained the land suitability surface through the MCE method. Then, we used the MOLA method for the initial optimization. Fig. 4. shows the MCE-derived land suitability output for each land use category.

The input data feeding objective functions during for MOLA allocation process were standardized in a range between 50 and 255. Table 4 shows the environmental and the economic objective functions.

Table 4 Environmental and economic objective function

$\begin{array}{lll}\text { Objective function } & \text { Object function type } & \text { Row } \\ \text { Min }=241 a a+50 a c+50 a w+255 a d+109 a r+109 a p & \text { Minimizing runoff } & 1 \\ & \text { depth } & \\ +137 f f+109 f p+50 c c+241 w a+50 w w+255 w d+109 w r+255 d d+241 r a & \end{array}$

Max $=152 a a+255 a c+254 a w+255 a d+101 a r+100 a p+152 f f+100 f p+255 c c$

$+152 w a+254 w w+255 w d+101 w r+255 d d+152 r a$

$+255 r c+255 r d+101 r r+100 r p+152 p f+101 p r+100 p p$
Maximizing land $\quad 2$ use profits

In Table 4, (aa) represents agricultural lands, (ff) forest lands, (cc) cold-water aquaculture lands, (ww) hydrothermal aquaculture lands, (rr) rangelands, (pp) protected areas and (dd) urban and rural development. Other decision variables represent the conversion of one land use to another, e.g., (aw) is agricultural land that can be converted into hydrothermal aquaculture and $(\mathrm{ra})$ is rangeland land that can be converted into agriculture.

According to Table 4, the objective functions of minimizing runoff depth and maximizing land use profits indicate that in order to optimize the MOLA-derived land use map with the aim of reducing the depth of runoff and increase profits, it is important to consider which land use is likely to convert to another and if these land uses are converted, how much runoff will be produced and how much profit is generated.

Then, each of the environmental groups and land developers designed their own constraints. Each group accepts its own constraints to continue the multi-objective linear planning process and rejects the other party's constraints. This conflict prevents the continuation of the land allocation process and stops the algorithm. Therefore, game theory was used to resolve the conflict. Table 5 shows the designed constraints of each group. 
Table 5 Limitations of each group

\section{Constraint}

Player

Row

(1):aa+ac+aw+ad+ar+ap+ff+fp+cc+wa+ww+wd+wr+dd+ra+rc+rd+rr+rp+pf+pr+pp=1895000;

Environmental

(2):Aa+ac+aw+ar+ap=285000; (3): $F f+f p=460000 ;(4): W a+w w+w d+w r=30000$;

(5):Pp+pf+pr=910000; (6):pp<810000; (7):pp>805000; (8):ff<400000; (9):ff >390000;

(10):cc<14000; (11):cc>12000; (12):pf+pr<100000; (13):pf+pr>90000; (14):aa<270000;

(15): $a a>200000 ;(16): r r<160000 ;$ (17): $r r>150000 ;(18): W w<25000 ;(19): w w>20000 ;$

(20): $d d=30000 ;(21): a c<=12307 ;(22): a w<=60000 ;(23): a d<=230000 ;(24): \operatorname{ar}<=51000$;

(25): $\mathrm{ap}<=45000 ;$ (26):fp<=334000; (27):wa<=60000; (28): $w d<37000 ;(29): w r<60000 ;$

(30):ra<=512000; (31):rc<=15000; (32):rd<=243000; (33):rp<=118000; (34):pf<=334000;

(35): $\mathrm{pr}<=118000$;

(1): $a a+a c+a w+a d+a r+a p+f f+f p+c c+w a+w w+w d+w r+d d+r a+r c+r d+r r+r p+p f+p r+p p=1895000$

Economic

(2):Aa+ac+aw+ar+ap=285000; (3): $F f=460000 ;(4): W a+w w+w d+w r=30000$;

(5): $P p+p f+p r=910000$;

(6): $\mathrm{Pf}<100000$; (7): $\mathrm{pf}>80000$; (8): $\mathrm{Pr}<100000 ;$ (9): $\mathrm{Pr}>80000 ;(10): \mathrm{Rr}<135000 ;(11): \mathrm{Rr}=130000$;

(12):Rc+rd+ra<30000; (13):Rc+rd+ra>25000; (14):Ww=15000; (15):Wd<=15000;

(16): $\mathrm{Cc}=15000 ;(17): \mathrm{Aa}=270000 ;(18): \mathrm{ac}<=12307 ;$ (19): $\mathrm{aw}<=60000 ;(20): \mathrm{ad}<=230000$;

(21): $\operatorname{ar}<=512000 ;(22): \operatorname{ap}<=45000 ;(23): w a<=60000 ;(24): w d<37000 ;(25): w r<60000 ;$

(26): $\mathrm{ra}<=512000 ;$ (27): $\mathrm{rc}<=15000 ;(28): \mathrm{rd}<=243000 ;(29): \mathrm{rp}<=118000 ;(30): \mathrm{pf}<=334000$;

(31): $\mathrm{pr}<=118000$;

Here A indicates agricultural use, $\mathrm{F}$ is forestry, $\mathrm{R}$ is rangeland, $\mathrm{D}$ is urban and rural development, W is hydrothermal water use, $C$ is cold water aquaculture and $P$ is conservation. Other variables indicate the conversion of one land use to another. Considering environmental constraints, constraints (1) to (5) relate to area limitations. Constraint No. (1) relates to the amount of required area (cell) from the entire study location. Constraint No. (2) indicates the amount of areas that should be converted to agriculture that have the required area (same as the area obtained from MOLA) and constraint No. (3) refers to areas that should be converted to forests that have the required area (area obtained from MOLA). Restriction No. (4) shows areas that need to be converted to hydrothermal aquaculture that have the required area (MOLA area) and restriction No. (5) is that areas should be converted to conservation that has the required area (MOLA area) constraint. Other limitations relate to environmental and technical constraints. In terms of economic constraints, constraints No. (1), (2), (4), (5) are related to area constraints and other constraints are related to economic, social and technical constraints. Table 5 shows that there should be constraints to achieve the desired objective functions. The unit of all of them is area (cell). The pixel size of each of the maps used in this research is 30 meters by 30 meters.

In this research, the prisoner puzzle game was used for the land use allocation game. Based on game elements, action A indicates the choice of its designed constraint and action B indicates the choice of the constraint designed by the other player. The third element of the game is the payoff of each player at each stage of the game. After running the game in Gambit 13.1 software, a stage of the game called Nash Equilibrium was achieved (Fig. 3). The concept of Nash Equilibrium indicates each player makes rational decisions, meaning that each player seeks to maximize his profit. In other words, Nash Equilibrium is a point at which if a player changes his game, his profit does not change (assuming the rest of the game is fixed). In the second game, the goal for each player was primarily to achieve environmental and economic goals and then to select the constraints designed by the players. To do this, first environmental objective function was implemented based on environmental and economic constraints separately designed in WINQSB software. Then, the same procedure was repeated for the economic function. Table 6 shows the results of the objective functions in the WINQSB software. The numbers in Table 6 show only the value of the objective function and are unitless. 
Table 6 Results of objective functions based on designed constraints

$\begin{array}{llll}\begin{array}{l}\text { With economic } \\ \text { constraints }\end{array} & \begin{array}{l}\text { With economic } \\ \text { constraints }\end{array} & \text { Object function type } & \text { The objective function }\end{array}$

$\begin{array}{lll} & \text { Minimizing runoff } & \begin{array}{l}\text { Environmental objective } \\ \text { volume }\end{array} \\ 261944992 & & \text { function }\end{array}$

Maximizing user profit Economic goal function

252247296

In the next step, the players make decisions according to the designed scenarios. The results of the game indicate that each player has chosen his own designed restrictions (Fig. 3). In the third game, the players' goal was to satisfy the other side based on the required areas and needs of the other side. To do this, both environmental and economic objective functions were implemented simultaneously with the designed constraints of the environment and in another stage with the designed economic constraints in WINQSB software. The results of performing the objective functions are presented in Table 7. The pixel size of each of the maps used in this research is 30 meters by 30 meters.

Table 7 Results of execution of objective functions in WINQSB software

\begin{tabular}{|c|c|c|}
\hline Land use & $\begin{array}{l}\text { Changing the area of land uses based } \\
\text { on socio-economic constraints (cell) }\end{array}$ & $\begin{array}{l}\text { Changing the area of land uses based on environmental } \\
\text { constraints (cell) }\end{array}$ \\
\hline Agriculture & $\begin{array}{l}\text { Agriculture ( } 270000 \text { cells), Agriculture } \\
\text { to cold water aquaculture (12307), } \\
\text { Agriculture to hydrothermal } \\
\text { aquaculture ( } 2693 \text { cells) }\end{array}$ & $\begin{array}{l}\text { Agriculture ( } 215000 \text { cells), Agriculture to cold water } \\
\text { aquaculture }(12307 \text { cells), Agriculture to hydrothermal } \\
\text { aquaculture }(47693 \text { cells), Agriculture to urban and rural } \\
\text { development ( } 10000 \text { cells), }\end{array}$ \\
\hline Forestry & Forestry $(460,000$ cells $)$ & Forestry (400000 cells), Forest to protection (60000 cells) \\
\hline $\begin{array}{l}\text { Cold water } \\
\text { aquaculture }\end{array}$ & Cold-water aquaculture (15000 cells) & Cold-water aquaculture (15000) \\
\hline $\begin{array}{l}\text { Hydrothermal } \\
\text { aquaculture }\end{array}$ & $\begin{array}{l}\text { Hydrothermal aquaculture ( } 15000 \\
\text { cells), Hydrothermal aquaculture to } \\
\text { urban development And rural ( } 15000 \\
\text { cells) }\end{array}$ & $\begin{array}{l}\text { hydrothermal aquaculture ( } 20000 \text { cells), hydrothermal } \\
\text { aquaculture for urban and rural development ( } 10000 \text { cells) }\end{array}$ \\
\hline $\begin{array}{l}\text { urban and } \\
\text { rural } \\
\text { development }\end{array}$ & $\begin{array}{l}\text { urban and rural development ( } 30000 \\
\text { cells) }\end{array}$ & urban and rural development (30000 cells) \\
\hline rangeland & $\begin{array}{l}\text { rangeland ( } 140000 \text { cells), rangeland } \\
\text { to urban and rural development } \\
(25000 \text { cells) }\end{array}$ & rangeland management (165000 cells) \\
\hline Protection & $\begin{array}{l}\text { Protection }(710000 \text { cells }), \text { Protection } \\
\text { to forestry }(100,000 \text { cells), protection } \\
\text { to rangeland }(100000 \text { cells })\end{array}$ & $\begin{array}{l}\text { Protection ( } 810000 \text { cells), Protection to forestry (100000 } \\
\text { cells) }\end{array}$ \\
\hline
\end{tabular}

After running the game in Gambit 13.1 software, the third stage of the game was obtained under the Nash Equilibrium state. At this stage, each player selects the constraints designed by the environment, and the payoff is the environmental player ten and the economic player five. Due to the solution of the game, the environmental player is declared as the winner of the game, and with this result, the conflict is created, and then, it is possible to resolve and continue the process of allocating land use. Accordingly, land use optimization continues throughout the multi-objective linear programming process with constraints designed by environment (Fig. 4). 
Linear programming is not an originally spatial method and the results are in the form of changing the area of each land use and converting one land use to another, for the final optimization according to the defined set of goals. Locations that have the least suitability for the initial land use and the highest suitability for the converted land use should be changed. In order to find these areas, the map layers were cross-tabulated. In the next step, there were different solutions for locating these areas. In this regard, we extracted the land use whose area needs to be changed and then we ranked the MOLA-derived map and extracted the desired area from this layer. These areas were then reclassified based on land use category, and finally overlaid with MOLA map. This process was implemented for the results of multi-objective linear planning and the final land use optimization map was configured using goal programing and GIS. Table 8 shows the comparison between new MOLA areas and the initial optimization areas and the probability of runoff depth of each land use based on old and new MOLA maps with L-THIA method.

Table 8 sensitivity analysis and comparison of runoff area and depth probability with old and new MOLA maps

\begin{tabular}{|c|c|c|c|c|c|c|c|}
\hline $\begin{array}{l}\text { C runoff } \\
\text { depth }(\mathrm{cm})\end{array}$ & $\begin{array}{l}\text { B runoff } \\
\text { depth }(\mathrm{cm})\end{array}$ & $\begin{array}{l}\text { A runoff } \\
\text { depth }(\mathrm{cm})\end{array}$ & $\begin{array}{l}\mathrm{C} \text { area } \\
\text { (cell) }\end{array}$ & $\begin{array}{l}\text { B area } \\
\text { (cell) }\end{array}$ & $\begin{array}{l}\text { A area } \\
\text { (cell) }\end{array}$ & Land use & Row \\
\hline 1896.5 & 1587.5 & 1644.7 & 370000 & 215000 & 285000 & Agriculture & 1 \\
\hline 754.3 & 743.4 & 754.3 & 460000 & 500000 & 460000 & Forestry & 2 \\
\hline 647.2 & 508.1 & 508.1 & 130000 & 165000 & 165000 & Rangeland & 3 \\
\hline 2732.4 & 2237.4 & 2197.7 & 119000 & 50000 & 30000 & $\begin{array}{l}\text { Urban and rural } \\
\text { development }\end{array}$ & 4 \\
\hline 0 & 0 & 0 & 52000 & 67693 & 30000 & $\begin{array}{l}\text { War water } \\
\text { aquaculture }\end{array}$ & 5 \\
\hline 0 & 0 & 0 & 34000 & 27307 & 15000 & $\begin{array}{l}\text { Cold water } \\
\text { aquaculture }\end{array}$ & 6 \\
\hline \multirow[t]{2}{*}{453.6} & 498.2 & 508.1 & 730000 & 870000 & 910000 & Protection & 7 \\
\hline & & & 1895000 & 1895000 & 1895000 & & Sum \\
\hline
\end{tabular}

In Table 8, A means the initial MOLA land use map that has been used as the input of the L-THIA model. In addition, B and $\mathrm{C}$ are the land allocation maps resulted from linear programming model, once with the constraints of environmental stakeholders and once with the constraints of economic players.

The L-THIA model was implemented again with an end-use allocation map to determine the effect of the objective function (minimizing the probability of runoff depth) on reducing runoff depth. The results are presented in Table 8 and Fig.5.

Figure 6 shows the game elements and the form of games played during the execution of the algorithm.

The elements of the first game were as follows:

Players $=(E N, E C)$.

Action $=(A 1, B 1)$.

Action profile $=(A 1, A 1),(A 1, B 1),(B 1, A 1),(B 1, B 1)$

Utility = the profit of each player in choosing each action of the game's steps is as follows:

Page 12/23 
$\operatorname{UEn}=(A 1, B 1)=10$, UEc $=(A 1, B 1)=5($ Step $A$ of the game $)$

$\mathrm{UEn}=(\mathrm{A} 1, \mathrm{~A} 1)=5, \mathrm{UEc}=(\mathrm{A} 1, \mathrm{~A} 1)=5($ Step $\mathrm{B}$ of the game $)($ Nash equilibrium $)$

UEn $=(B 1, B 1)=2$, UEc $=(B 1, B 1)=2($ Step $C$ of the game $)$

UEn $=(B 1, A 1)=3$, UEc $=(B 1, A 1)=10($ Step $D$ of the game $)$

According to elements of the game, action A indicates the choice of its own designed constraint and action B indicates the choice of the other constraint designed by the player. The third element of the game is the payoff of each player at each stage of the game. The elements of the game in the second stage are as follows:

Players $=(E N, E C)$

Action $=(A 1, B 1)$.

Action profile $=(A 1, A 1),(A 1, B 1),(B 1, A 1),(B 1, B 1)$

Utility = the profit of each player in choosing each action of the game's steps is as follows:

UEn $=(A 1, B 1)=10$, UEc $=(A 1, B 1)=4($ Step $A$ of the game $)$

$\mathrm{UEn}=(\mathrm{A} 1, \mathrm{~A} 1)=6, \mathrm{UEc}=(\mathrm{A} 1, \mathrm{~A} 1)=6($ Step $\mathrm{B}$ of the game $)($ Nash equilibrium $)$

UEn $=(B 1, B 1)=2$, UEC $=(B 1, B 1)=2($ Step $C$ of the game $)$

UEn $=(B 1, A 1)=4$, UEc $=(B 1, A 1)=10($ Step $D$ of the game $)$

Finally, the elements of the game in the third stage were defined as follows:

Players $=(E N, E C)$.

Action $=(A 1, B 1)$.

Action profile $=(A 1, A 1),(A 1, B 1),(B 1, A 1),(B 1, B 1)$

Utility = the profit of each player in choosing each action of the game's steps is as follows:

$\mathrm{UEn}=(\mathrm{A} 1, \mathrm{~B} 1)=10, \mathrm{UEC}=(\mathrm{A} 1, \mathrm{~B} 1)=5($ Step $\mathrm{A}$ of the game $)($ Nash equilibrium $)$

UEn $=(A 1, A 1)=8$, UEc $=(A 1, A 1)=3($ Step $B$ of the game $)$

$\mathrm{UEn}=(\mathrm{B} 1, \mathrm{~B} 1)=3, \mathrm{UEC}=(\mathrm{B} 1, \mathrm{~B} 1)=4($ Step $\mathrm{C}$ of the game $)$

UEn $=(B 1, A 1)=2$, UEC $=(B 1, A 1)=3($ Step $D$ of the game $)$

After running the game, the step A of the game obtained the game's balance. At this stage, each player selects the constraints designed by the environmentalists, and the payoffs are the environmental player ten and the economic player five. According to the solution of the game, the environmental player is declared as the winner of the game, and with this result, it is possible to resolve the conflict and continue the process of land use optimization. Accordingly, land use assessment continues with constraints designed by the environmentalists. Each stage of the game had its own Nash Equilibrium, but it should be noted that once the game reaches the Nash Equilibrium, the player does not change his strategy in any way. In the first and second games, stage B of the game, each of the stakeholders selects his own 
designed constraints (Fig. 6). The output of this stage of the game was the Nash Equilibrium but the game conflict was still unresolved and it was not possible to continue the process of land use optimization. Fig. 7 shows the final land use map of the study area using the land allocation model based on linear programming and game theory.

\section{Discussion}

In the third phase of the game, more emphasis was placed on the bargaining power of the game theory, and the goal of the players in making decisions was grounded on this basis. Table 7 shows the results of the execution of the objective functions with their corresponding constraints. Each player must first prioritize the needs of the other party based on the required area, which is accordingly translated as a constraint. With environmental constraints, 70,000 cells should be allocated from agricultural to aquatic use and hydrothermal and cold water use and rural-urban development. With this result, attention has been paid to the needs of the economic players considering production of labor, increasing profits and reducing the initial cost of establishing each land use. Under such designed limitations, the economic player of 15,000 cells from agriculture should be allocated to aquaculture, cold water and hydrothermal applications.

Environmental constraints have also improved economic landscape of the area by changing agricultural land uses, while not reducing forest and natural ecosystems, which play a key role in reducing runoff and erosion. In addition, in the second stage, with this change in agricultural use, the concerns of environmentalists for protecting forests are also taken into account. With the limitation of the environmental player, about 60,000 cells should be allocated to forest protection, and consequently, proper attention has been paid to such environmental aspects. But according to designed limitations, the economic player of forestry will remain intact. Namely, more attention has been paid to the economic aspects of forestry than to the environmental needs of the other side. Cold-water aquaculture will remain unchanged in both constraints. 10,000 cells of hydrothermal water use should be allocated to urban and rural development based on the designed constraints of the environment (considering socio-economic aspects through changing economic uses). 15,000 cells of this land use should be converted to urban and rural development according to the designed constraint of economic domain. The use of urban and rural development will remain unchanged in both constraints. Due to its role in reducing runoff and erosion, as well as its economic aspects such as forage production, livestock grazing and beekeeping, the use of rangeland habitat will remain unchanged in the designed environmental constraints. But with the economic constraints, 25,000 cells of this land use must be allocated to urban and rural development. Therefore, less attention has been paid to the needs of the other side and most of the socio-economic aspects are considered. Finally, with the designed environmental constraints, 100,000 cells should be allocated from conservation land use to forestry. With this allocation, attention has been paid to both socio-economic and environmental aspects of forestry. Forestry use will reduce runoff and erosion, and also provides shelter and habitat for wildlife. On the other hand, 200,000 protection cells should be allocated for rangeland and forestry use. Therefore, the area of environmental protection activities will be reduced, and less attention will be paid to the needs of the other party.

In stage B of the third game, each player will choose their own designed restrictions. According to the rules of the game, the environmental player will get 8 points and the economic player will get 3 points assuming that the environmental player will not change his game, if the economic player wants to change his game and choose the designed environmental constraints (moving from stage B to stage A of the game). In this case, his score will increase from 3 to 5 points. Therefore, according to the definition of Nash Equilibrium, stage $B$ of the game cannot maintain the equilibrium state.

In stage A of the game, each player will choose the designed environmental constraints. Based on game scenarios, the environmental player gets 10 points and the economic player gets 5 points. Assuming that the environmental player is not willing to change his game, if the economic player wants to change his game (move from stage A to stage B) and his score will be reduced from 5 to 3; so refuses to change his game. Also, assuming the economic player is fixed, if the environmental player wants to change his game and chooses the economic constraint (moving from stage $A$ to stage $C$

Page 14/ 23 
of the game), then his score will be reduced from 10 to 3 and the environmental player will not be willing to change his game. As mentioned, because none of the players are willing to change their game, stage $A$ of the game will be considered as the equilibrium state and steps $C$ and D, as defined by Nash, cannot reach the Nash Equilibrium.

The preferences of the environmental player on each of the outputs in the third phase of the game are as follows:

Step $A>$ Step $B>$ Step $C>$ Step D.

The preferences of the economic player on each of the outputs in the game with the third repetition are as follows:

Step A > Step C > Step B > Step D.

Given the players' preferences for each output, it is clear that the strategy of designed environmental constraints is strongly dominant as an action; because it takes into account both environmental and socio-economic aspects (through environmental economics) and the results are practical. In contrast, the strategy of choosing the constraint designed by the economic player is selected as a strongly defeated action since the other side is highly dissatisfied due to its low score in the game scenarios.

\section{Conclusion}

We applied a game with environmental and economic constraints for land use optimization. For this, multi-objective linear programming with environmental constraints was adopted and the result was fed into the MOLA process. Comparing the optimal output areas of the multi-objective linear programming model and game theory with the initial land use areas showed the need for changing the current area and configuration land use categories in the region. The results of the integrated model suggested a reduction of 6,300 hectares from agricultural land use, to achieve the environmental objectives such as possible reduction of runoff depth and soil erosion. Around 3,600 hectares were added to forest land use to address the needs of the environmental and socio-economic sectors. The area of warm and cold water aquaculture as well as urban and rural land uses were increased during the optimization process to meet socioeconomic goals. Eventually, 3,600 hectares were reduced from protected areas and allocated to forestry. Forestry plays an important role in safeguarding the environmental objectives (reducing the potential runoff depth and the erosion likelihood), and on the other hand, it helps achieving the socio-economic goals. According to the studied socio-economic parameters, the desirability of forestry is far greater than the protected areas, which could provide an interesting topic for further studies in the region. Future studies can evaluate the potential of ecologically-friendly activities such as forestry and recreation in improving socio-economic status of the region, while protecting its valuable ecological functions and ecosystem services. Future models can also quantify the role of tourism and its interaction with other land use categories in the region to establish a spatial decision support system for informed and multi-objective land use planning. By referring to Table 8, the sensitivity in changes of the runoff depth can be understood by changing the inputs of the L-THIA model using different inputs such as different land use maps. It is clear that with different land allocation maps, runoff outputs were expected to be commensurate with them. Also, by comparing the runoff depth of each land use, it can be found that the final land allocation map in this study will provide a more acceptable runoff depth.

This research is one of the first attempts in combining game theory with MOLA and linear programming models and according to the results, the model can lead to conflict resolution between different stakeholders. The integrated model suggested in this study, is less complex and the results are easier to interpreted compared to similar studies based on application of game theory, genetic algorithm and fuzzy sets theory (mentioned in the introduction). Therefore, as a topic of further research, the mode can be further implemented in other research areas with different sets of land use categories and influential stakeholders to evaluate the potential of such integrative studies in conflict resolution and sustainable development plans.

Page 15/23 


\section{Declarations}

\section{Data Availability:}

The datasets generated during and/or analyzed during the current study are available from the corresponding author on reasonable request.

\section{Conflict of Interest Statement:}

The authors undertake that there is no conflict of interest to declare.

\section{References}

Adhami, M. Sadeghi, S, H. Duttmann, R. Sheikhmohammady, M. (2020). Best soil comanagement practices for two watersheds in Germany and Iran using game theory-based approaches. Science of The Total Environment. 698. 134265. https://doi.org/10.1016/j.scitotenv.2019.134265.

Aerts, J. C., Eisinger, E., Heuvelink, G., Stewart, T. J. (2003). Using linear integer programming for multi-site land-use allocation. Geographical Analysis, 35, 148-169. https://doi.org/10.1111/j.1538-4632.2003.tb01106.x.

Arthur, J. L., Nalle, D. J. (1997). Clarification on the use of linear programming and GIS for land-use modelling. International Journal of Geographical Information Science, 11, 397-402. https://doi.org/10.1080/136588197242338.

Asadollahi, Z., SalmanMahiny, A. (2017). Assessing the Impact of Land Use Change on Ecosystem Services Supply (Carbon Storage and Sequestration). Environmental Reserches. 15, 203-

214. https://dorl.net/dor/20.1001.1.20089597.1396.8.15.24.0.

Aumann, R.J. (1985). What is game theory trying to accomplish? In: Arrow, K., Honkapohja, S. (Eds.), Frontiers of Economics. Basil Blackwell, Oxford. https://doi.org/10.4236/ns.2010.23033.

Bahadori, B. Harbor, J. Engel, B. and Grove, M. (2000). Assessing Water-Scale, Long-Term Hydrologic Impacts of Land-use change Using a GIS-NPS Model. Journal Environment Management. (26): 643-658. https://doi.org/10.1002/j.15518833.1997.tb08325.x.

Batty, M. (2018). Artificial Intelligence and Smart Cities. SAGE Publications Sage UK, London, England.

Bočková, K.H., Sláviková, G., Gabrhel, J. (2015). Game theory as a tool of project management. Procedia - Social Behav. Sci. 213, 709-715. http://dx.doi.org/10.1016/j. sbspro.2015.11.491.

Camerer, C.F. (1997). Progress in behavioral game theory. J. Econ. Perspect. 11 (4), 167188. http://dx.doi.org/10.1257/jep.11.4.167.

Census Yearbook of Golestan Province. (2013). A. S. Mhiny. 1-200.

Cao, K., Batty, M., Huang, B., Liu, Y., Yu, L., Chen, J. (2011). Spatial multi-objective land use optimization: extensions to the non-dominated sorting genetic algorithm-II. Int. J. Geogr. Inf. Sci. 25, 19491969. https://doi.org/10.1080/13658816.2011.570269.

Carraro, C., Marchiori, C., Sgobbi, A. (2007). Negotiating on water: insights from noncooperative bargaining theory. Environ. Dev. Econ. 12 (2), 329-349. http://dx.doi.org/10.1017/S1355770X06003536. 
Chen, J. (2007). Rapid urbanization in China: A real challenge to soil protection and food security. Catena, 69, 115. https://doi.org/10.1016/j.catena.2006.04.019.

Chuvieco, E. (1993). Integration of linear programming and GIS for land-use modelling. International Journal of Geographical Information Science, 7, 71-83. https://doi.org/10.1080/02693799308901940.

Chuvieco, E. (2004). Integration of linear programming and GIS for Land-Use Modelling. International Journal of Geographical Information System 7(1): 71-83.

Collins, B, C. Kumral, M. (2020). Game theory for analyzing and improving environmental management in the mining industry. Resources Policy. 69. 101860. https://doi.org/10.1016/j.resourpol.2020.101860.

Drobne, S. Lisec, A. (2009). Multi-attribute decision analysis in GIS: weighted linear combination and ordered weighted averaging, Informatica, 33(4): 459-474.

Ducourtieux, O. Laffort, J.R. and Sacklokham, S. (2005). Land policy and farming practices in Laos. Dev. Change. 36: 499526. https://doi.org/10.1111/j.0012-155X.2005.00421.x.

Engle, B. A. Choi, J, Y. Harbor, J. and Pandey, S. (2003). Web-based DSS for hydrologic impact evaluation of small watershed land use changes. Computers and electronics in agriculture. (39): 241-249. http://dx.doi.org/10.1016/S01681699(03)00078-4.

Gu, Y. Lord, A. Eika, A. Dethier, P. Samsura, D, A, A. Nordahi, B, I. Sommervoll, D, E. Krabben, E. Halleux, J. (2021). Fair shares? Advancing land economics through cooperative game theory. Land Use Policy. 106.

105400. https://doi.org/10.1016/j.landusepol.2021.105400.

Guoxin, T., Shibasaki, R., Matsumura, K. (2004). Development of a GIS-based decision support system for assessing land use status. Geo-Spatial Inf. Sci. 7, 72-78. https://doi.org/10.1007/BF02826679.

Hasti, F. SalmanMahiny, A. Jolaei, R. Aghili, S, M. (2016). Game Theory, a useful approach for resolving land use planning. Journal Environment and development. (12): 43-54. (In Persian with English abstract).

Hasti, F. Rouhi, H. Khodakarami, L. Mahiny, A. S. (2016). Zoning the protected area of Shahoo/Kosalan using RS and GIS. IOSR Journal of Environmental Science, Toxicology and Food Technology (IOSR-JESTFT). 10: 8. 74-

81. http://dx.doi.org/10.9790/2402-1008017481 .

Homayounfar, M., Ganji, A., Khalili, D., Mousavi, A.A. (2010). A model for reservoir operation based on the game theory. Iran-water Resour. Res. 6 (2), 14-26 (In Persian with English abstract).

Hui, E., Bao, H. (2013). The logic behind conflicts in land acquisitions in contemporary China: A framework based upon game theory. Land Use Policy, 30, 373-380. http://dx.doi.org/10.1016/j.landusepol.2012.04.001.

Ikonen. P. Rantala, M. Miettinen, J. Kuittinen, S. Hujala, T. Mehtätalo, L. Pappinen, A. (2020). Grounds for improving the implementation of game-oriented forest management - A double sampling survey of Finnish forest owners and professionals. Forest Policy and Economics. 119. 102266. https://doi.org/10.1016/j.forpol.2020.102266.

Jana, A. Basu, R. Mukherijee, C. (2020). A game theoretic approach to optimize multi-stakeholder utilities for land acquisition negotiations with informality. Socio-Economic Planning Sciences. 69.

100717. https://doi.org/10.1016/j.seps.2019.06.002.

Kaiser, E.J., Godschalk, D.R., Chapin, F.S. (1995). Urban Land Use Planning. University of Illinois Press, Urbana, IL. 
Lee, C.S., Chang, S.P. (2005). Interactive fuzzy optimization for an economic and environmental balance in a river system. Water Res. 39 (1), 221-231. http://dx.doi.org/10.1016/j.watres.2004.09.013.

Lee, C.S. (2012). Multi-objective game-theory models for conflict analysis in reservoir watershed management. Chemosphere 87 (6), 608-613. http://dx.doi.org/10.1016/j.chemosphere.2012.01.014.

Li, X., Yeh, A. G.-O. (2000). Modelling sustainable urban development by the integration of constrained cellular automata and GIS. International Journal of Geographical Information Science, 14, 131-152.

https://doi.org/10.1080/136588100240886.

Li, X., \& Yeh, A. G.-O. (2002). Neural-network-based cellular automata for simulating multiple land use changes using GIS. International Journal of Geographical Information Science, 16, 323-343. https://doi.org/10.1080/13658810210137004.

Li, X., Shi, X., He, J., \& Liu, X. (2011). Coupling simulation and optimization to solve planning problems in a fastdeveloping area. Annals of the Association of American Geographers, 101, 10321048. https://doi.org/10.1080/00045608.2011.577366.

Ligmann-Zielinska, A., Church, R.L., Jankowski, P. (2008). Spatial optimization as a generative technique for sustainable multiobjective land-use allocation. Int. J. Geogr.Inf. Sci. 22, 601-622. https://doi.org/10.1080/13658810701587495.

Liu, X., Li, X., Shi, X., Huang, K., Liu, Y. (2012). A multi-type ant colony optimization (MACO) method for optimal land use allocation in large areas. International Journal of Geographical Information Science, 26, 13251343. https://doi.org/10.1080/13658816.2011.635594.

Liu, Y., Wang, L. Long, H. (2008). Spatio-temporal analysis of land-use conversion in the eastern coastal China during 1996-2005. Journal of Geographical Sciences, 18, 274-282. https://doi.org/10.1007/s11442-008-0274-3.

Liu, Y., Liu, D., Liu, Y., He, J., Jiao, L., Chen, Y. (2012). Rural land use spatial allocation in the semiarid loess hilly area in China: Using a particle swarm optimization model equipped with multi-objective optimization techniques. Science China Earth Sciences, 55, 1166-1177. https://doi.org/10.1007/s11430-011-4347-2.

Liu, Y., Wang, H., Ji, Y., Liu, Z., \& Zhao, X. (2012). Land use zoning at the county level based on a multi-objective particle swarm optimization algorithm: A case study from Yicheng, China. International Journal of Environmental Research and Public Health, 9, 2801-2826. https://doi.org/10.3390/ijerph9082801.

Liu, Y. Tang, W. He, J. Liu, Y. Ai, T. Liu, D. (2015). A land-use spatial optimization model based on genetic optimization and game theory. Computers, Environment and Urban Systems. 49(1-

14). http://dx.doi.org/10.1016/j.compenvurbsys.2014.09.002.

Liu, Y. Hu, Y. Hu, Y. Gao, Y. Liu, Zh. (2021). Water quality characteristics and assessment of Yongding New River by improved comprehensive water quality identification index based on game theory. Journal of Environmental Sciences. 104. 40-52. https://doi.org/10.1016/j.jes.2020.10.021.

Lund, J.R., Palmer, R.N. (1997). Water resource system modeling for conflict resolution? Water Resour. 3 (108), 70-82. Ma, Y. (2004). L-THIA: A useful hydrologic impact assessment model. Journal Nature and Sciences. (2): 68-73.

Maleki, J. Masoumi, Z. Hakimpour, F. coello ,C , A. (2020). A spatial land-use planning support system based on game theory. Land Use Policy. 99, 105013. https://doi.org/10.1016/j.landusepol.2020.105013 
Mazandaran Zadeh, H., Ghaheri, A., Abdoli, G. (2010). A conflict resolution model among municipal and agricultural users by game theory for sustainable operation of a common aquifer. Eqtesad-E Keshavarzi Va Towse'e 17 (4), $77-102$ (In Persian with English abstract).

Mohammadi Limaei, S. (2006). Economically Optimal Values and Decisions in Iranian Forest Management, Doctoral Thesis. Swedish University of Agricultural Sciences, Umea, Sweden (No 2006: 91). http://urn.kb.se/resolve? urn=urn:nbn:se:slu:epsilon-1245.

Mohammadi Limaei, S. (2007). A game theory approach to the sawn wood and pulpwood markets in the north of Iran. Caspian J. Environ. Sci. 5 (1), 1-10.

Mohammadi Limaei, S. (2010). Mixed strategy game theory, application in forest industry. For. Policy Econom. 12 (7), 527-531. http://dx.doi.org/10.1016/j.forpol.2010.06.009.

Mohammadifar, A. Gholami, H. Comino, J, R. Collins, A, L. (2021). Assessment of the interpretability of data mining for the spatial modelling of water erosion using game theory. CATENA. 200.

105178. https://doi.org/10.1016/j.catena.2021.105178.

Moradi, S. Mohammadi Limaei, S. (2018). Multi-objective game theory model and fuzzy programing approach for sustainable watershed management. Land Use Policy. 71. 363-371. https://doi.org/10.1016/j.landusepol.2017.12.008.

Myerson, R.B. (1992). On the value of game theory in social science. Ration. Soc. 4, 62-

73. https://econpapers.repec.org/scripts/redir.pf?

u=http\%3A\%2F\%2Frss.sagepub.com\%2Fcontent\%2F4\%2F1\%2F62.abstract,h=repec:sae:ratsoc:v:4:y:1992:i:1:p:62-73.

Nazari, S. Ahmadi, A. Kamrani Rad, S. Ebrahimi, B. (2020). Application of non-cooperative dynamic game theory for groundwater conflict resolution. Journal of Environmental Management. 270.

110889. https://doi.org/10.1016/j.jenvman.2020.110889.

Nikkami, D. Elektorowicz, M. Mehuys, G. R. (2002). Optimizing the management of soil erosion. Journal Water Qual. Res. J. Can. 37: 3. 577-586

Ozsari, S. Uguz, H. Hakli, H. (2021). Implementation of meta-heuristic optimization algorithms for interview problem in land consolidation: A case study in Konya/Turkey. Land Use Policy. 108.

105511. https://doi.org/10.1016/j.landusepol.2021.105511.

Pfaff, A.S.P. Sanchez-Azofeifa, G.A. (2004). deforestation pressure and biological reserve planning: a conceptual approach and an illustrative application for Costa Rica. Resour. Energy Econ. 26: 237-

254. http:// doi:10.1016/j.reseneeco.2003.11.009.

Parrachino, I., Dinar, A., Patrone, F. (2006)a. Cooperative Game Theory and Its Application to Natural, Environmental, and Water Resource Issues: 3. Application to Water Resources. pp. 4074 (World Bank Policy Research Working Paper No. 4074, WPS4074, Washington, DC). http://hdl.handle.net/10986/8848.

Parrachino, I., Zara, S., Patrone, F. (2006)b. Cooperative Game Theory and Its Application to Natural, Environmental, and Water Resource Issues: 1. Basic Theory. (World Bank Policy Research Working Paper No. 4072, WPS4072, Washington, DC).

Pourzand, F., Zibaei, M. (2010). Application of game theory for the optimal groundwater extraction in Firozabad plain. J. Agric. Econ. 5 (4), 1-24 (In Persian with English abstract). http://www.iranianjae.ir/article_9484_en.html. 
Rasmusen, E. (2001). Games and information: An introduction to game theory. Wiley- Blackwell.

Riedel, C. (2003). Optimizing Land Use Planning for Mountainous Regions using LP and GIS towards Sustainability. Journal of Soil Conservation. USA, 34(1): 121-124.

Rodrigues, A., Koeppl, H., Ohtsuki, H., Satake, A. (2009). A game theoretical model of deforestation in humanenvironment relationships. J. Theor. Biol. 258 (1), 127-134. http://dx.doi.org/10.1016/j.jtbi.2009.01.005.

Raquel, S., Szidarovszky, F., Coppola Jr., E., Rajano, A. (2007). Application of game theory for a groundwater conflict in Mexico. J. Environ. Manage. 84 (4), 560 571.http://dx.doi.org/10.1016/j.jenvman.2006.07.011.

Sadeghi, S. Jalili, K. Nikkami, D. (2009). Land use optimization in watershed scale. Land Use Policy, 26, 186-193. https://doi.org/10.1016/j.landusepol.2008.02.007.

Shabani, M. (2010). Effect of optimizing land use on eroion and benefit of watershed: the case study of Zakhard watershed in Fars province. Iran. J. Natur. Geog. 8: 83-98.

Shahi, Ch., Kant, Sh. (2007). An evolutionary game-theoretic approach to the strategies of community members under Joint Forest Management regime. For. Policy Econ. 9 (7), 763-775. http://dx.doi.org/10.1016/j.forpol.2006.04.002.

Samsura, D.; Ary A.; Van der krabben, E. \& Van Deemen, A.M.A. (2010). A game theory approach to the analysis of land and property development processes. Land Use Policy 27 (2010) 564-

578. https://doi.org/10.1016/j.landusepol.2009.07.012.

Shields, D.J., Tolwinski, B., Kent, B.M. (1999). Models for conflict resolution in ecosystem management. Socio-Econ. Plann. Sci. 33 (1), 61-84. http://dx.doi.org/10.1016/S0038-0121(98)00003-2.

Sobuhi, M., Mojarad, E. (2010). Application of game theory for groundwater resources management of atrak. J. Econ. Agric. Dev. 24 (1), 1-12 (In Persian with English abstract). https://www.sid.ir/en/Journal/ViewPaper.aspx?ID=195240.

Song, M., Chen, D. (2018). An improved knowledge-informed NSGA-Il for multi-objective land allocation (MOLA). GeoSpatial Inf. Sci. 21, 273-287. https://doi.org/10.1080/10095020.2018.1489576.

Tang, D. Liu, H. Song, E. Chang, Sh. (2020). Urban expansion simulation from the perspective of land acquisition-based on bargaining model and ant colony optimization. Computers, Environment and Urban Systems. 82.

101504. https://doi.org/10.1016/j.compenvurbsys.2020.101504.

Üçler, N., Onkal Engin, G., Köçken, H.G., Öncel, M.S. (2015). Game theory and fuzzy programming approaches for biobjective optimization of reservoir watershed management: a case study in Namazgah reservoir. Environ. Sci. Pollut. Res. 22 (9), 6546-6558. http://dx.doi.org/10.1007/s11356-015-4181-8.

Weng. Q. (2001). Modeling Urban Growth Effects on Surface Runoff with the Integration of Remote Sensing and GIS. Journal Environment Management. (28): 737-748. http://dx.doi.org/10.1007/s002670010258.

Wu, Y., Wu, C., \& Shen, L. (2005). Modeling the decision-making using game theory in monitoring land-use practice in China. Systems Engineering - Theory \& Practice, 9, 65-70. http://hdl.handle.net/10397/33223.

Wu, X., Grubesic, T. H. (2010). Identifying irregularly shaped crime hot-spots using a multiobjective evolutionary algorithm. Journal of Geographical Systems, 12, 409-433. https://doi.org/10.1007/s10109-010-0107-7. 
Yazdian, M. Rakhshandehroo, Gh. Nikoo, M, R. Ghorbani Mooselu, M. Gandomi, A, H. Honar, T. (2021). Groundwater sustainability: Developing a non-cooperative optimal management scenario in shared groundwater resources under water bankruptcy conditions. Journal of Environmental Management. 292.

112807. https://doi.org/10.1016/j.jenvman.2021.112807.

Ye, Ch, Chen, L. Zhou, J. (2021). Evaluation model of forest eco economic benefits based on discrete particle swarm optimization. Environmental Technology \& Innovation. 22. 101426. https://doi.org/10.1016/j.eti.2021.101426.

Zhang, W. (2004). Game theory and information economics. Shanghai People's publishing House.

Zhang, Y., Li, A. Fung, T. (2012). Using GIS and multi-criteria decision analysis for conflict resolution in land use planning. Procedia Environmental Sciences, 13, 2264-2273. https://cyberleninka.org/article/n/458151.

\section{Figures}
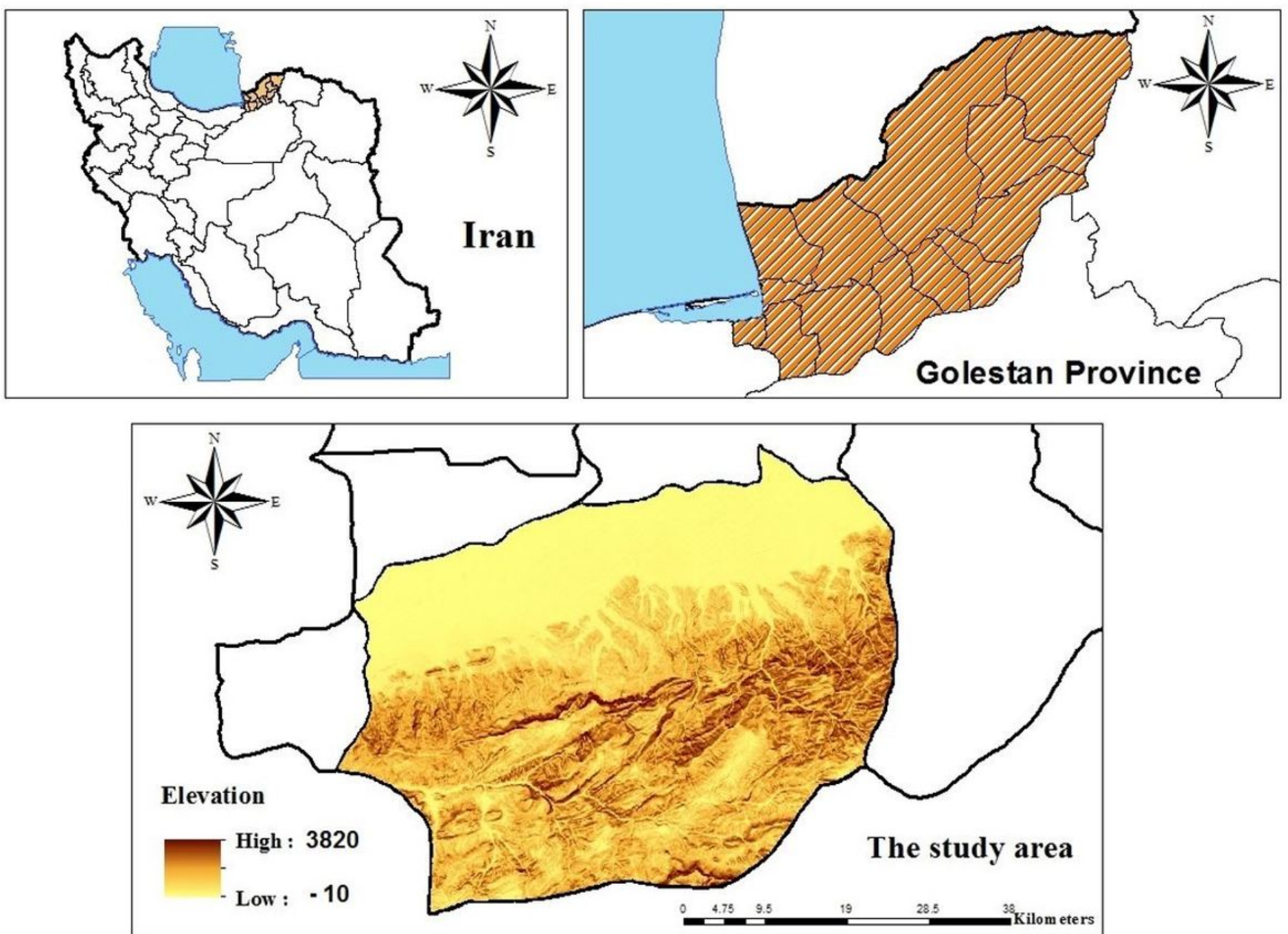

Figure 1

The geographic location of the study area 
Figure 2

Research flow chart

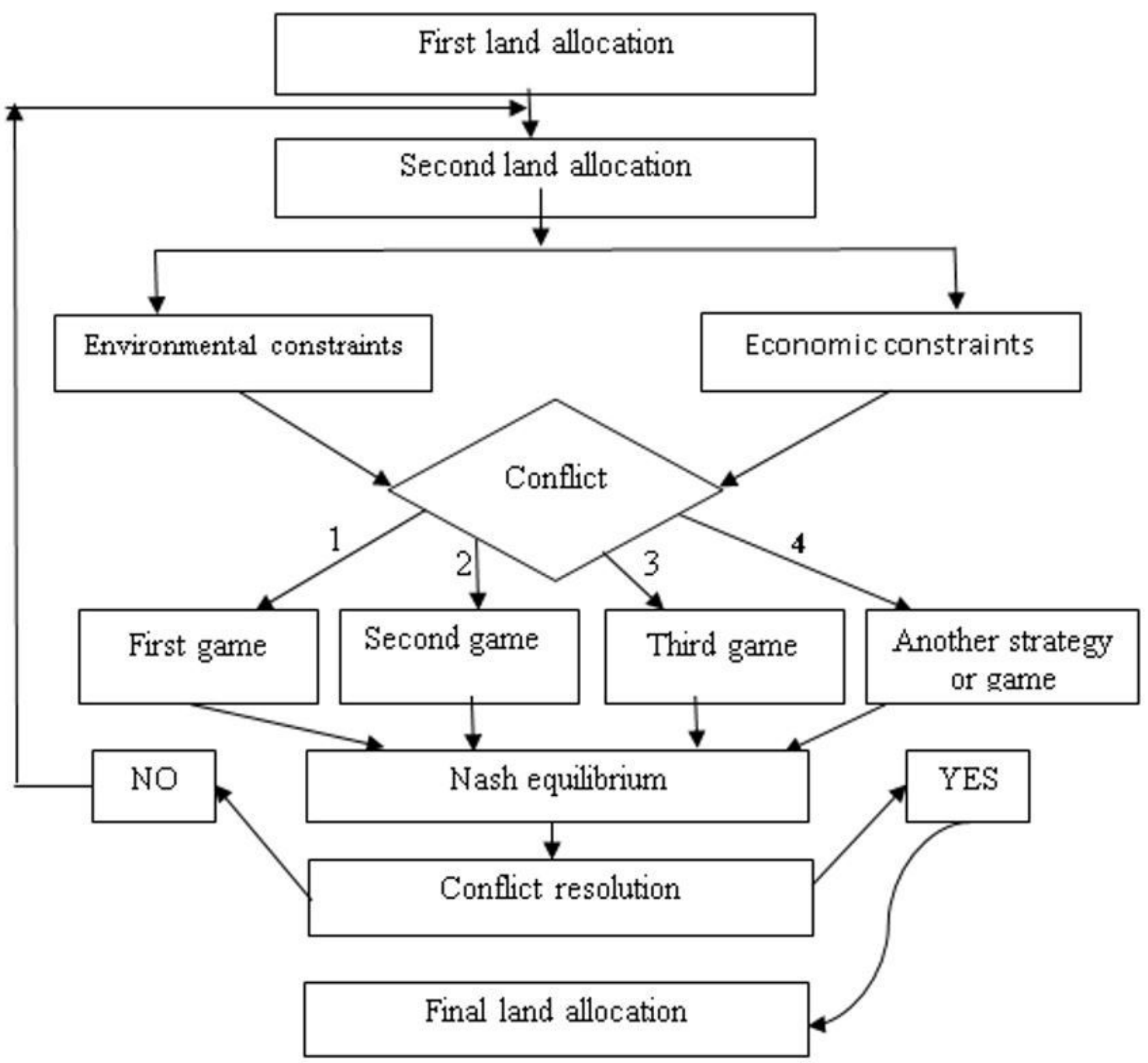

Figure 3

General study framework and game algorithm for land use allocation

Figure 4

Land suitability derived from the MCE method 
Figure 5

Execution of L-THIA model with initial and final optimization results

Figure 6

Elements and form of the games

Final land allocation
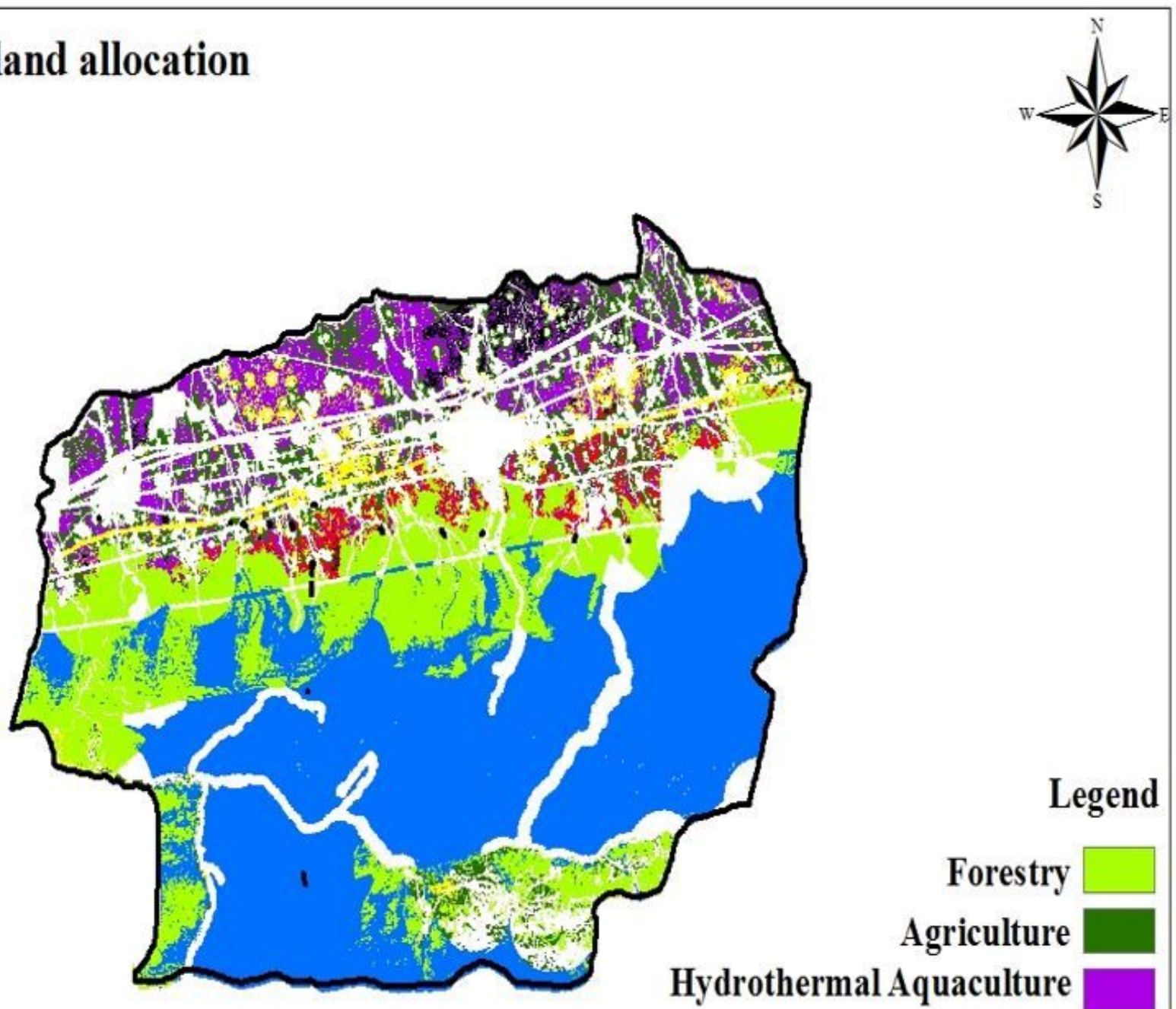

Cold-water aquaculture

Urban \& Rural Development

Protection

Figure 7

Final land allocation 